\title{
section affairs
}

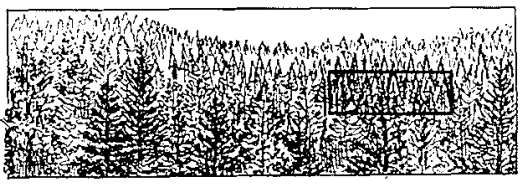

\section{Algonquin and \\ Ottawa Valley}

The multiple use concept, as applied to Algonquin Park, was of concern to the $80 \mathrm{mem}$ bers of the Algonquin and Ottawa Sections during a joint field trip on Oct. 24. Members of the Press were invited to this meeting.

Freezing weather and periodic snow flurries did not dampen the enthusiasm of the discussion on all aspects of the topics as defined by the members of the Dept. of Lands and Forests staff: forestry by Chuck Gray, conflicts in land use by the Park naturalist Bill Calvert, and wildlife and fish management by Mike Wilton. The group met at the Sand Lake gate to the Park at $8.45 \mathrm{a} . \mathrm{m}$. and was welcomed both by Jack Clements, Chairman of Algonquin Section and John Oatway, Acting District Forester. Chris Yeatman gave a review of some of the "Algonquin Park issues".

Consolidated-Bathurst and the Canadian Forestry Service assisted in bus transportation. Thirty-four students of Algonquin College's Forestry Technician course together with their instructors, joined the trip in their own vehicle. Jim Brown was in charge of the day's program and was ably assisted by the three moderators, Charlie Van Wagner, Leo Sayn-Wittgenstein and Jim Cayford. Our vital needs were most satisfactorily attended to by the Dept. of Lands and Forests (morning coffee break), Herb and David Noik of the Pem- broke Lumber Co. (lunch at Lake Traverse), and Local Forest Operators (supper at Achray).

Bill Calvert showed the "visual presentation" prepared for the visiting public and commented on its good reception. The presentation of plastic bags to the campers on registration, to be returned (filled) to the Park

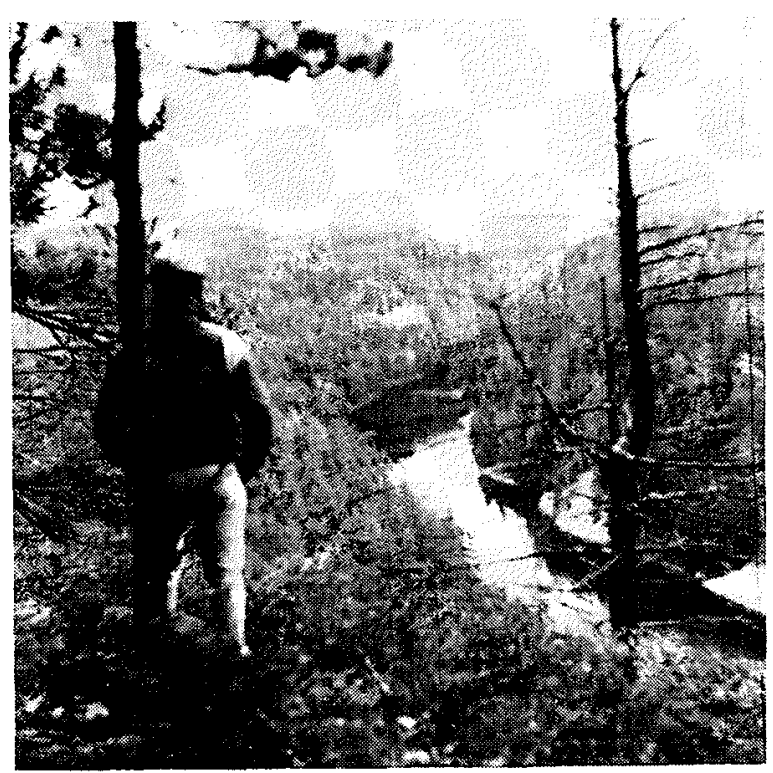

Objective achieved. Barron River Canyon - scene of a lively discussion on natural areos. 


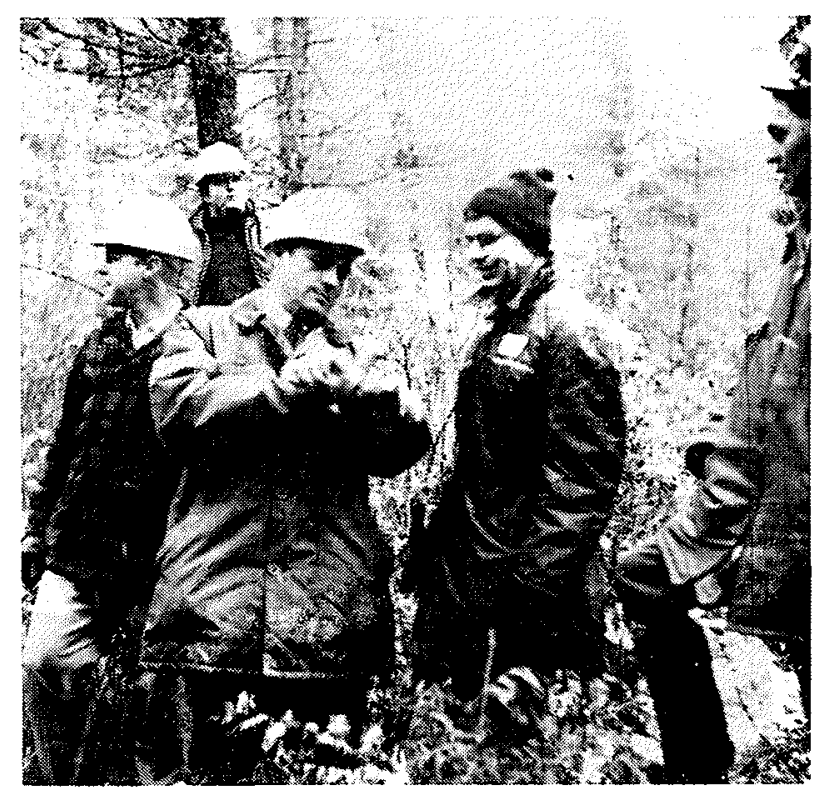

Chuck Gray checking the time - Charlie Van Wagner (centre) keeps the Algonquin Park field trip on schedule.

attendant on departure, is designed to solve the garbage disposal problem. Herb Beall, when summarizing the day's events at a sitdown session after dinner, singled out the benefits of the release of the red pine understory from the jack pine overstory some 15 years ago as demonstrated at the Petawawa Forest Experiment Station, where the jack pine was not removed, this species at comparable age was now wind-thrown - a good argument for selective logging to maintain not only a healthy and productive but also visually attractive forest.

The Barron River canyon presented an extremely picturesque setting. Opinions on its management for maximum utilization of its potential for recrea-

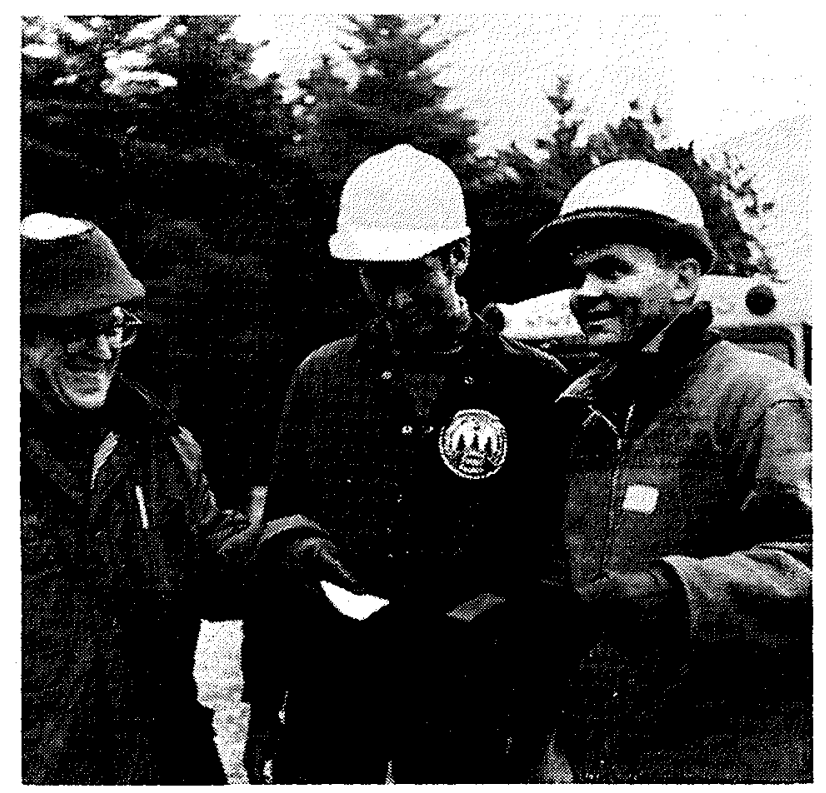

Left to right: Dave Wigston, Algonquin College student with Larry Scales and John Oatway Algonquin Park field trip, Oct. 24 tion were varied. The "naturalists" were somewhat surprised to learn from foresters present that the far side of the gorge could be selectively logged with little or no visual disturbances and that removal of some trees, such as the white pine infected with blister rust, would lead to a healthier stand.

During discussions on the regeneration-strip shelterwood system by Chuck Gray, the necessity of combining harvesting with recreation was again stressed. The new mill of Consolidated-Bathurst's at Portage du Fort, would in the future, permit the utilization of all trees removed during silvicultural treatments. This was, for economic reasons, not feasible in the past and we saw the unsightly dead girdled trees. Harvesting of wildlife as part of total management was discussed. In a multiple-use concept, hunting, which after all is a form of recreation, has a definite place.

In the Lake Traverse area the final disposal of a private club building after its lease expires was discussed. Although some naturalists suggested that it be torn down to allow the area to revert to " $\mathrm{Na}$ ture", a more sensible suggestion was that this

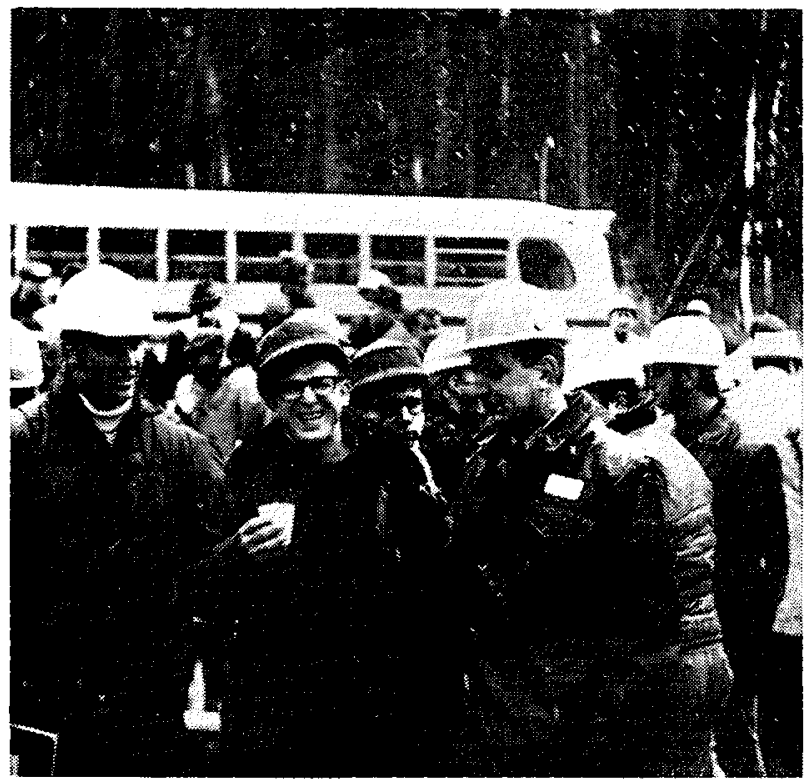

Instructors of Algonquin College Forestry Technicion course Larry Scales (left) and Bill Collins (right) explain a point on multiple use to one of their students.

massive and unique log building be maintained as a historical building to illustrate the past history of logging. It would form a suitable repository for Tom Thomson's paintings (original or otherwise). Jack Robinson, whose father had been Park Superintendent mentioned the little known fact that this famous Canadian (one of the Group of Seven) was stationed for two summers, 1915-1916, at Achray, as a Park ranger.

A deer yard past Lake Traverse was the next stop. Here the red maple and poplar were bulldozedover to provide food for deer. While this treatment was producing the desired effects, i.e. food for deer, the visual effect of the tangled mass of undergrowth was rather disconcerting.

Even the fisheries aspect was not neglected. Lake 
trout fishing in Grand Lake is poor and it was suggested that it could be considerably improved by the reconstruction of the dam controlling the water outlet. This would raise the water sufficiently to increase the spawning territory available. The only difficulty, besides the financial one, which was not discussed, would be the modification of the beach line. This would affect both shore birds or the nonfishing members of the family that prefer sandy beaches, because beaches would be reduced both in number and width. While the suggestion was made that instead of water-depth control the fish species should be adjusted to existing conditions through the introduction of bass, we wonder if the fact that those fish which suffer from a parasite infection which renders them unattractive for human consumption, should not warrant special consideration. As always, time did not permit detailed discussion on all the topics.

Vic Stewart, Chairman of the Ottawa Valley Section, thanked all the participating groups and individuals at the end of a long but enjoyable day.

D. A. Fraser

\section{Lake of the Woods}

Lake of the Woods Section was privileged to share in a joint field meeting with members of the Manitoba Section and the Upper Mississippi Valley Section of the SAF on September 19th and 20th.

The meeting was hosted by the Manitoba Section and took form as a social rendezvous at Falcon Lake on the evening of September 18th, then a field trip next day around south eastern Manitoba. Highlights of the field trip were a visit to the Chip Board plant and sawmill at Sprague, a "Woodsy" smorgasbord near Piney, a tour of the Sandilands viewing a red pine seed production area, scarification for site preparation, prescribed burn areas, then finally a tour of the Pineland Nursery before returning to Falcon Lake.

Most of the group stayed to enjoy a barbecue at Falcon Lake that evening.

A brief business meeting was held the following day before members dispersed.

The Annual Meeting in Prince George was attended by 4 members and their wives from this section, J. Godden, D. Start, J. Pohanka, and G. J. Garner. Mr. Garner was our representative to the Board of Directors meeting and in his subsequent report circulated to section members he termed the meeting an unqualified success.

Our next Section meeting is scheduled for Dryden on December 6th, 1969.

\section{K. A. Alexander}

\section{Northwestern Ontario}

Thirty-seven members and guests attended the C.I.F. tour of the Domtar limits on August 22 to see two silvicultural projects. Ernie Smith, resident forester, Domtar and George Market, unit forester, Geraldton district, were the hosts for the afternoon. During the evening, section chairman Alex Bartho- lemew conducted a busiriess meeting and later led a discussion on the events of the day.

The field trip was divided into two tours. The North tour, out of camp 51, featured tree length logging in 100 and 150 foot strips with scarification to produce spruce and jackpine natural regeneration. Members from the Northern and Eastern parts of the section attended this tour. The South or Limestone lake tour attracted the members from south of Beardmore and the Lakehead. Plantations of black and white spruce on cutovers, repeated burns and rehabilitated scrub land were seen with commentary by George Marek. The success of these plantations cannot be doubted.

It is apparent from the attendance and comment on this tour that regeneration, in all its forms, is a major interest and concern to many foresters. Ample evidence was presented to confirm the fact that regeneration can be obtained on all productive unforested land regardless of its condition, if we apply ourselves to the job. It is also a fact of artificial regeneration that the task is complicated by costs which are spiralling upward as for all logging jobs which require a very high labour content. This field trip presented two contrasting techniques - the traditional clear-cut and plant versus the modern clear-cut in strips and scarify immediately for natural reproduction. It is claimed that the latter method requires less cash outlay. Which technique should we support? Clear-cut, plant and pay or clear-cut in strips, scarify and save?

The section owes a vote of thanks to John Goodman for his work to make this tour an unqualified success.

Thanks to E. R. Humphreys, Kimberley-Clark, Longlac for this report on the Domtar tour; $\mathrm{Mr}$. Humphreys has been appointed by the North West section council to submit a full account to The Log Book.

J. Goodman, section vice-chairman, Dept. Lands and Forests, Geraldton, has replaced A. Bartholomew on the school of forestry advisory committee at Lakehead University. Specific advisory committees have been appointed for each university school to provide a closer liaison with the professions, business and industry.

C. Johnson

\section{Nova Scotia}

Meeting at Keltic Lodge on Cape Breton Island section members decided that there is an immediate need for a forest policy to guide government, industry and forest land owners in Nova Scotia. Working committees are being organized and a forest policy statement will be presented to government not later than June 30, 1970.

The 13th Annual Meeting, held last September 15 and 16 , highlighted William P. House, consultant forester and chairman of New Hampshire's forest policy committee. The meeting theme "Sailing Without a Compass - A Need for a Forest Policy?" featured a number of speakers. George Ross, now with the Canadian Pulp \& Paper Association, dis- 


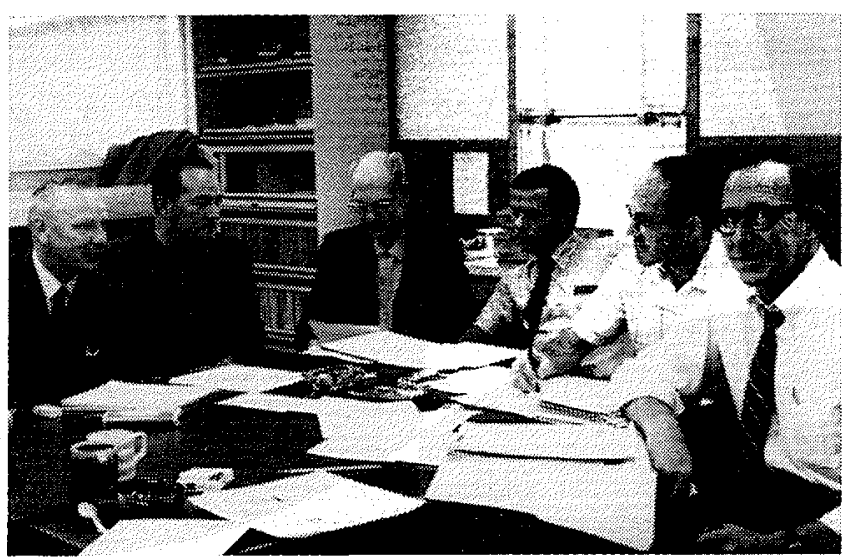

Nova Scotia Section Members planning the 1969 annual meeting. From left to right: Don Levy, director; Don Eldridge, past chairman; Leif Holt, section chairman; Jack Dunlop, section secretary; Gary Sounders and Fred Cuming, program co-chairmen for the i3th annual meeting.

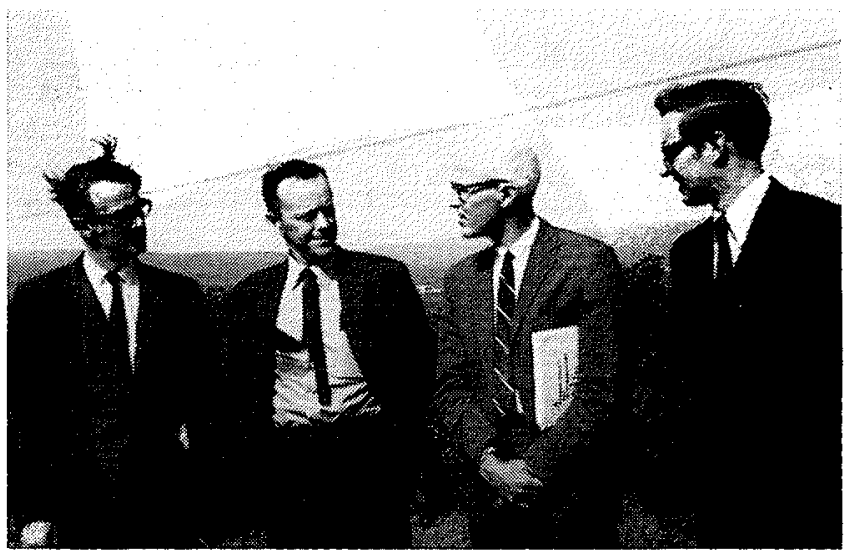

Leadoff speakers at Nova Scotia's 13th annual meeting at Keltic Lodge. Left to right: Dick Bulmer (Inventory), George Ross (Wood Supply), William House (New Hampshire's Forest Policy), and Ron Daly (Nova Scotia's Farest Impravement Act).

cussed wood supply and planning. Ron Day, Provincial Forest Practices Board, summarized Nova Scotia's Forest Improvement Act, and Dick Bulmer, covered Nova Scotia's provincial forest inventory.

Other speakers included: Tom McLelan, McLelan Lumber Company; Hollis Routledge, Nova Scotia Pulp Company; Evan Lloyd, Cape Breton Tourist Association; Hugh Fairn, Nova Scotia Wildlife Federation; L. J. Post, Ontario Department of Lands and Forests; Gordon Baskerville, Department of Fisheries and Forestry; and Don Levy and Richard Michaud, Nova Scotia Department of Lands and Forests.

The various speakers were grouped under the subjects of. Industry and Utilization, Multiple Use, and Research and Planning.

Highlighting the dinner was Edmund Morris, of St. Mary's University and a noted TV and radio commentator, and the presentation of the "Order of Good Cheer" to Mr. House by Lands and Forests Minister G. A. Snow. Mr. Morris challanged the Nova Scotian Foresters to choose between destructive exploitation and good forestry. He contrasted the "Belsen and the Michaelangelo" attitude of people, and the poverty of the Judean Hills with the forest wealth of Nova Scotia. Entertainment at the dinner was in the form of prize awards to

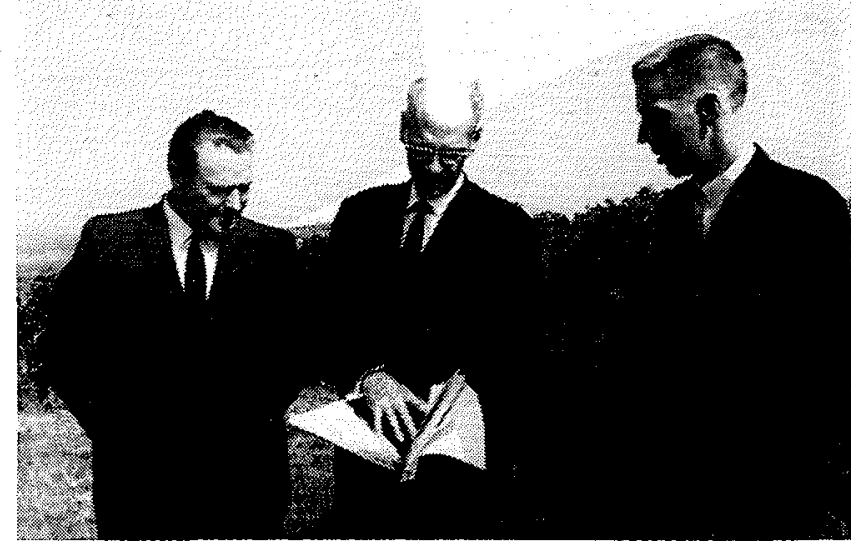

Nova Scotia Section's chairman Leif Holt (center) with Industry and Utilization speakers Hollis Routledge (left) of N.S. Pulp Ltd. and Tom McLelan (right) of McLelan Lumber Company.

Robert Burgess, Byron Flieger, Richard Bulmer and John Dunlop for excellence and outstanding ability during the Sunday golf tournament. Dr. Roy Strang's toast to the foresters wives was graciously replied to by Mrs. Donald Eldridge.

G. D. Dwyer

\section{Orléans}

Compte-rendu de l'assemblée annuelle pour l'année 1968-69

Cette assemblée tenue le 1 er mai 1969 à l'HôtelMotel Universel Inc. réunissait une vingtaine de membres, sous la présidence de monsieur John Conway.

Le compte-rendu de l'assemblée générale du 27 février 1969 fut tout d'abord lu par le secrétairetrésorier et accepté à l'unanimité après proposition de monsieur G. Lortie, secondé par monsieur $S$. Mackay.

Monsieur le président fit alors remarquer qu'on avait donné suite aux principales propositions faites lors de cette réunion et qu'il avait reçu ou recevrait sous peu la documentation nécessaire pour supporter les nominations de la Section pour le "Canadian Forestry Achievement Award" et pour l'élection d'un membre honoraire. De plus les démarches nécessaires ont été faites pour proposer que la Section Orléans soit l'hôte de I'Institut Forestier du Canada lors de son congrès annuel de 1977.

\section{Rétrospective des affaires de la section}

Après avoir brossé un rapide tableau des activités de notre section au cours de l'année écoulée, monsieur John Conway fit remarquer que ces activités ne répondaient que partiellement aux objectifs que nous nous sommes fixés. En effet, un des rôles importants de notre section est de promouvoir l'intérêt et la connaissance d'une pratique forestière saine chez le public, et presque rien n'a été accompli en ce sens. A l'avenir, il faudrait s'efforcer davantage à réaliser ce but. 


\section{Comité de politiques forestières}

Le rôle principal du comité de politiques forestières au cours de l'année a été de recueillir et de résumer sous forme d'un rapport, qui sera envoyé au président du comité national de politiques forestières, l'opinion des membres de la section au sujet de l'énoncé des politiques forestières de l'Institut préparé par ce comité national. Ce rapport préparé par $M$. P. Vézina a été approuvé à l'unanimité (Sirois/Roberge). On pourra en trouver une copie dans le rapport annuel.

Monsieur Conway informa alors l'assemblée d'une lettre qu'il avait fait parvenir à monsieur $E$. S. Fellows, président du Comité National de Politiques Forestières, pour lui souligner le fait que l'étude du rapport par les membres de notre section, aurait été facilitée si celui-ci avait été rédigé en français.

On peut résumer de la façon suivante les principaux points qui ressortent de la discussion dans laquelle l'assemblée s'est ensuite engagée:

- Etant donné qu'il regroupe un nombre important de personnes évoluant dans les domaines les plus divers de la foresterie, et ce, dans toutes les régions du Canada, l'Institut Forestier du Canada peut et doit se prononcer en matière de politiques forestières.

- L'Institut forestier autant au niveau national qu'à l'échelle de la section devrait plus souvent prendre position dans des champs de sa compétence.

- Il est urgent que l'Institut adopte une politique forestière bien définie, par conséquent il ne devrait pas y avoir trop de rapports préliminaires.

\section{Comité de recrutement}

Le président du Comité de recrutement, monsieur $P$. E. Vézina lut et commenta le rapport qu'il avait préparé en collaboration avec les autres membres de ce comité. On trouvera ce rapport joint au rapport annuel.

Les principaux points qui ressortent de la discussion suivant la présentation de ce rapport sont les suivants:

- Une définition en termes plus pratiques et mieux précisés des buts de l'Institut serait un atout important pour faciliter le recrutement de nouveaux membres.

- Il semble que le secrétariat central prépare actuellement la publication d'un pamphlet expliquant et précisant les objectifs de l'Institut Forestier du Canada.

- Il y aurait probablement lieu de repenser les diverses catégories de membres de l'Institut, et ce, surtout au niveau des membres actifs et affiliés. En effet, plusieurs chercheurs autres que des forestiers, mais évoluant en foresterie, ne sont pas intéressés à faire partie de l'Institut car ils ne sont pas considérés comme membre à part entière.

La réunion d'affaires fut suivie d'un excellent dîner et de la présentation d'un film commenté par M. Antoine Dubuc.

Ce très intéressant film, propriété de $M$. Dubuc, illustre les diverses phases de la fabrication du papier journal telle qu'elle se faisait en 1916, à Chicoutimi, Chandler et Nevv York.

Claude Desloges

\section{Saskatchewan}

John Gilmour supervised a group of seventy-four students from the Renewable Resources Technology course at the Saskatchewan Institute of Applied Arts and Sciences on a tour of the Aspenite plant, MacMillan and Bloedel, in Hudson Bay, Sask. The mid-October tour was a welcome chance for the students to see the direct utilization of part of Saskatchewan's poplar potential.

In September R. M. Waldron of the Liaison and Services Section of the Federal Department of Fisheries and Forestry supervised a scarification demonstration in the Nisbet Forest, Sask.

The forest cover, before cutting, originated from a fire in 1919 and consisted of about 800 stems per acre of pure jack pine. The area was clear-cut in strips ten chains wide at five chain intervals. Slash from the operation was windrowed.

The scarification equipment provided by the Department of Fisheries and Forestry consisted of six Ontario shark-finned barrel scarifiers as designed by $G$. Brown of the Ontario Department of Lands and Forests. These barrels, filled with water and weighing 1300 pounds each, were pulled across the strips at right angles to the windrows by a tractor. (See photo). A minimum of thirty per cent of the mineral soil was exposed.

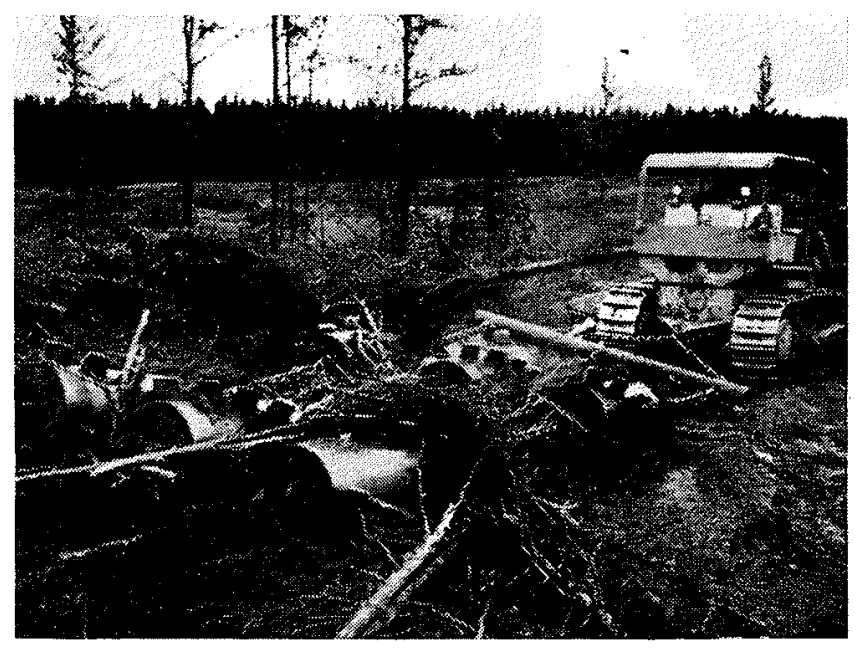

Mr. Waldron pointed out that this demonstration was based on the results of many research experiments and as such it was possible to predict, with some degree of certainty, that the scarified area would be successfully regenerated to jack pine.

For comparison a similar adjacent area was scarified using three anchor chains weighing about 800 pounds each. The system used was the same as with the barrel scarifiers. In each case some thirty acres were scarified at a rate of three to four acres per hour.

The areas will be examined in the future to evaluate the relative success of the two methods.

J. A. Benson 


\section{Vancouver Island}

Our long absence from Section Affairs should in no way be taken as a sign of malaise. The V. I. Section is active, healthy and solvent with a membership of 175 .

1969-70 Section Chairman Roy Sworder and his council have planned an active year. Gerry Burch, Chief Forester for B.C. Forest Products Limited keynotes the season's theme "Forestry in B. C. Where are we going?" at the first dinner meeting October 24th. At subsequent meetings speakers from various land-water use management agencies will examine areas of conflict.

Work has started towards making the 1971 annual meeting at Victoria the forestry highlight of the century.

As part of our campaign to broaden public interest and understanding of forest management a speakers bureau has been formed. Section members stand ready to talk to Vancouver Island service clubs on a variety of forest topics.

We were much encouraged to learn that the $\mathrm{V}$. I. Section Policy Statement and Policy Guide submission received a fair measure of support from other sections at the Prince George annual meeting. A copy of this statement was mailed to each Section in July.

We are of the opinion that the issuance of a national policy statement has been over-long in coming. If C.I.F. is ever to stand up to be counted in forestry matters it is essential that we have a published statement of policy.

We contend that such a statement must fill a two-fold purpose: first, it must guide the officers of C.I.F. Second and infinitely more important, it must proclaim to the general public that C.I.F. speaks for forest land management in Canada. If it is to perform this second function it must be lean of language and readily understood. We cannot hope to capture every regional peculiarity or special interest in a national statement. We can set down a clear manifesto which states our chief convictions. We should make a statement now and give it the widest possible publicity in the press and to our legislators.

If under the cold hard light of public scrutiny it fails in some measure - it can be changed without undue loss of position or dignity.

We do not argue that the $V$. I. Section statement should necessarily be the final choice - we do suggest that it provides a workable format from which a clear concise national statement can develop in a very short space of time.

We urge all other sections to re-examine their position on the National Policy Statement with the objective of a finalized statement early in 1970 .

D. N. Radcliffe

\section{MEMBERSHIP}

All undergraduates, graduates and post-graduates of accredited university forestry schools, or of other disciplines who are now working in a field allied to forestry or who are engaged in the practice of, teaching of, or research in a branch of forestry or related science are eligible as members of the Canadian Institute of Forestry — Institut Forestier du Canada.

If you wish further information forwarded on Institute membership or on THE FORESTRY CHRONICLE please complete and return the following form:

Secretary-Manager,

CANADIAN INSTITUTE OF FORESTRY - INSTITUT FORESTIER DU CANADA,

Box 5000, Macdonald College, P.Q.

Please forward information to: -

NAME

ADDRESS

Membership in the Institute

Subscription to THE FORESTRY CHRONICLE

Advertising in THE FORESTRY CHRONICLE

contacted by:

$$
\text { Print Name }
$$

Signature

(contact need not be a member of the Institute) 